\title{
Pyrazolopyrimidine Derivatives as Antineoplastic Agents: with a Special Focus on Thyroid Cancer
}

\author{
Silvia Martina Ferrari ${ }^{1}$, Concettina La Motta ${ }^{2}$, Stefania Sartini ${ }^{2}$, Enke Baldini ${ }^{3}$, Gabriele Materazzi $^{4}$, \\ Ugo Politti $^{1}$, Ilaria Ruffilli ${ }^{1}$, Salvatore Ulisse ${ }^{3}$, Paolo Miccoli ${ }^{4}$, Alessandro Antonelli ${ }^{*}$ and \\ Poupak Fallahi ${ }^{1}$
}

${ }^{I}$ Department of Clinical and Experimental Medicine, University of Pisa, Pisa, Italy; ${ }^{2}$ Department of Pharmacy, University of Pisa, Pisa, Italy; ${ }^{3}$ Department of Experimental Medicine, "Sapienza" University of Rome, Rome, Italy; ${ }^{4}$ Department of Surgical, Medical, Molecular Pathology and Critical Area, University of Pisa, Pisa, Italy

\begin{abstract}
Tyrosine kinase inhibitors (TKIs) are molecules that compete with ATP on tyrosine kinase receptors (TKRs), blocking tyrosine kinase (TK) activation and then oncogenic pathways; they have been studied, and some of them are right approved for the treatment of many types of cancer. Among TKIs, one of the most explored chemical template is the pyrazolo[3,4-d]pyrimidine (PP) heterocyclic core, which proved to be a useful scaffold for the obtainment of effective compounds. Actually,

A. Antonelli derivatives belonging to this structural class show a large spectrum of activity, thus standing out as multi-target agents. Different PP compounds have been shown to act as: a) ABL inhibitors and antiproliferative agents against human leukemia cell lines; b) Src kinase inhibitors in neuroblastoma, medulloblastoma and osteosarcoma; c) Phospholipase D inhibitors in different neoplasias; d) Urokinase plasminogen activator inhibitors, in breast cancer. In thyroid cancer (TC), PP1 and PP2 (inhibitors of RET, Hck, lck, and fynT kinases, and a good inhibitor of c-Src and platelet-derived growth factor receptor) showed antineoplastic actvity in human papillary TC cell lines that carry spontaneous RET/PTC1 rearrangements. More recently, new derivatives, (R)-1-phenethyl-N-(1-phenylethyl)-1H-pyrazolo[3,4-d]pyrimidin-4amine, namely, CLM3 and CLM29, have been demonstrated to exert a multiple signal transduction inhibition (including the RET-TK, BRAF, EGFR, and with antiangiogenic activity), showing antineoplastic activity, in vitro and in vivo, in papillary dedifferentiated, medullary and anaplastic TC. These data have shown the antineoplastic activity of PP in different neoplasias, opening the way to a future clinical evaluation in human cancers.
\end{abstract}

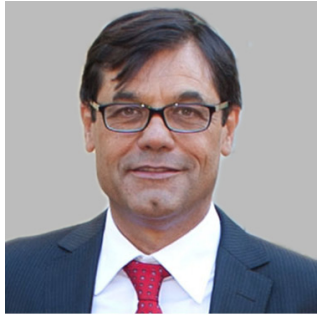

Keywords: Antiangiogenic inhibitors, CLM29, CLM3, PP1, PP2, pyrazolo[3,4- $d$ ]pyrimidine, RET inhibitors, tyrosine kinase inhibitors.

\section{INTRODUCTION}

In the last years several mutations and pathogenic mechanisms leading to onset of tumors, or their dedifferentation and resistance, were discovered. It was shown the cornerstone role of tyrosine kinases (TKs) and tyrosine kinase receptors (TKRs), like epidermal growth factor receptor (EGFR), vascular endothelial growth factor receptor (VEGFR), RET, BRAF, RAS/RAF/ERK and RAS/PI3K/AKT pathways, that are capable of causing cell transformations, giving mitogenic and survival signals, for example in thyroid cancer (TC) [1-6], and in other neoplasias [7-9].

Furthermore recently, it has been shown the importance of cytokines and chemokines [10] (usually involved in

\footnotetext{
*Address correspondence to this author at the Department of Clinical and Experimental Medicine, University of Pisa, Via Savi, 10, 56126, Pisa, Italy; Tel: +39-050-992318; Fax: +39-050-553235;

E-mail: alessandro.antonelli@med.unipi.it
}

autoimmune disorders $[11,12])$ in tumorigenesis of TC [13$15]$, and in other cancers $[16,17]$.

TKs and TKRs are actually targets of new antineoplastic therapies. Tyrosine kinase inhibitors (TKIs) are molecules that compete with ATP on TKRs, blocking TK activation and then oncogenic pathways [18].

Recently, some TKIs have been studied [1, 19-24], and some of them are right approved for the treatment of some types of cancer, as imatinib (for chronic myelogenous leukemia [25] and gastrointestinal stromal tumors [26]), sorafenib (for advanced renal cell carcinoma [27], advanced hepatocellular carcinoma [28], and radioactive iodine resistant advanced TC [29]), vandetanib and cabozantinib for medullary thyroid cancer (MTC) [30-33], and others [34].

Among TKIs, pyrazolopyrimidines-derived compounds are produced and tested as useful antineoplastic agents. The pyrazolopyrimidines are constituted by a pyrazole ring fused with the pyrimidine moiety differently from the imidazole moiety in purines $[35,36]$. At the beginning, 
pyrazolopyrimidines were studied as adenosine receptor antagonists [37]. Different chemical compounds with pyrazolopyrimidines as central core were produced [38] and recently Mahajan et al. published a paper about ACK1-TK targeted cancer cells inhibition of proliferation, including pyrazolo[3,4-d]pyrimidines derivatives [39]. There are several isomeric forms of pyrazolopyrimidines with various mechanisms of action and possible purposes like antiviral [40], anticoccidials [41], antimicrobial [42-44], antitumor $[45,46]$, antileukemic [47], tuberculostatic [48], radioprotectant [49], and several other activities [50].

\section{ANTINEOPLASTIC ACTIVITY}

Pyrazolopyrimidines were evaluated against different targets as RET, VEGFR, EGFR, ABL, SRC, Aurora kinase, and others, each employed in the upset, progression and trasformation of many tumors.

\subsection{ABL Inhibitors}

Manetti et al. [51] examined the role of the pyrazolo[3,4d]pyrimidines as ABL inhibitors and their antiproliferative action on human leukemia cell line. The effect of substituting different groups, as halogens and the hydrophobic regions of the ATP binding, was demonstrated by molecular modeling studies, showing its determinant activity on the affinity toward Abl. Pyrazolo[3,4-d]pyrimidines were produced by Radi et al. [52, 53] with an inhibitory effect in hypoxic human leukemia cells and the in vitro "absorption, distribution, metabolism, and excretion" (ADME) properties and metabolic activities were shown. The abovementioned molecules inhibited the Bcr-Abl kinase, increased caspase- 3 action and the cleavage of poly-ADP-ribose-polymerase.

\subsection{SRC Inhibitors}

Tintori et al. [54] evaluated the antineoplastic activity against neuroblastoma cell proliferation. A subclass of nonreceptor TKs as target in the treatment of human cancers is the Src-family TKs. Among these, c-Src was found to stimulate cell proliferation, migration, and invasion as well as angiogenesis [55]. Hyperactivation of c-Src leads to aberrant cell activity that contributes to cancer development. Elevated expression levels of c-Src have been shown in different types of cancer and are associated with a poor prognosis with respect to overall survival. Moreover, recent studies suggest that c-Src could be associated with the development of acquired drug resistance [56].

The antiproliferative and proapoptopic effects of pyrazolo[3,4-d]pyrimidines as Src kinase inhibitors in human osteosarcoma cells have been evaluated [57], concluding that they are capable in stimulating apoptosis and decreasing the Src phosphorylation. The inhibitory action of the compounds has been demonstrated to be dose dependent, via DNA damage or via increasing apoptosis.

New pyrazolo[3,4-d]pyrimidine derivatives as Src kinase inhibitors able to arrest cell cycle at G2/M phase and reduce growth of human medulloblastoma cells were produced [58].

\subsection{Aurora Kinases Inhibitors}

In 2012, 1,6-disubstituted-1H-pyrazolo[3,4-d]pyrimidines as dual inhibitors of Aurora kinases and CDK1 were synthesized [59] and the structure activity relationship (SAR) was reported, revealing to be particularly strong in case of low distribution volumes, elevated clearance rate, satisfying ADME properties, and thus demonstrating to be a good antitumor agent in leukemia cells.

\subsection{Phospholipase D (PLD) Inhibitors}

PLD catalyzes the cleavage of phosphatidylcholine at the ester linkage-releasing choline and phosphatidic acid (PA) [60], that is a second lipid messenger belonging to different essential signaling and metabolic pathways [61], and is involved in the regulation of cellular functions mediating the enhancement of cell migration. The enhanced PLD activity and expression have been shown in different human cancer tissues [62-64]; PLD supports cells in initiating defence mechanisms, and its inhibition diminishes the ability of cells to adhere. Kulkarni et al. [65] evaluated the action of aminopyrazolopyrimidines, that have earlier been used as TKI [66] and dual inhibitors of tyrosine and phosphoinositide kinases [67], that were produced and used to initially screen the capability of purified bacterial PLD, strongly homologous to the human PLD.

These inhibitory molecules directly blocked enzyme/ vesicle substrate binding. Preliminary activity studies, performed by recombinant human PLDs in in vivo cell assays evaluating transphosphatidylation and head-group cleavage, showed inhibition in the mid- to low-nanomolar range in a physiological environment.

\subsection{Urokinase Plasminogen Activator (uPA) Inhibitors}

uPA converts the circulating plasminogen to the active plasmin, is secreted as an inactive single-chain proenzyme by various cell types and is able to bind to a specific membrane uPA receptor (uPAR), in this way existing in a soluble or cell associated form [68]. uPA is involved in cancer invasion and metastasization, as members of the matrix metalloproteinases family, and takes part in many physiological functions [69]. After binding to uPAR, uPA initiates versatile intracellular signal pathways regulating cell proliferation, adhesion, and migration, interacting with different integrins and vitronectin [70]. Urokinase is involved in many malignancies, in lung, breast, cervix, bladder, kidney, brain, and stomach [71, 72]. The cytotoxicity of several compounds was tested using sulforhodamine B assay [73] in the breast cancer cell line MCF-7, the liver cancer cell line HepG2, and the lung carcinoma cell line A549. Shamroukh et al. [74] showed that pyrazole derivatives inhibit the activity of the urokinase enzyme, that is able to reduce cell proliferation leading to growth inhibition, and exerting an anti-carcinogenic activity in MCF-7 breast and HepG2 liver cancer cells. The SAR of the tested compounds showed that whereas substituted amino group enhanced the activity. However, fusining another ring (oxazine, pyrimidine, or fused pyrimidine) to the pyrazole structure decreased the anticancer activity. 


\subsection{Generation of Reactive Oxygen Species}

The synthesis and anticancer activities of new pyrazolo[3,4-d]pyrimidine derivatives were evidenced by Rashad et al. [75] in 2011, as they generate reactive oxygen species (ROS) in human breast adenocarcinoma cells. Tumor cells are more sensitive than normal cells to the elevated levels of ROS present in cancer and increased by the supplementary oxidative stress created by anticancer agents, that causes injury to cellular components leading to cell death. The abovementioned compounds exert their antitumor effect partly owing to the production of $\mathrm{H} 2 \mathrm{O} 2$.

The pyrazolo[3,4-d]pyrimidines have in vitro cytotoxic activity against breast adenocarcinoma [76] producing hydrogen peroxide and other free radicals leading to oxidative distress. The potency of pyrazolo[3,4-d]pyrimidines was higher that the one of pyrazole; anticancer activity was increased if the sulfonyl group was present between pyrazolo[3,4-d]pyrimidine and 4-chlorophenyl moiety.

Imine-pyrazolopyrimidinones have been reported as antitumoral agents [46], by multiple stress pathways in tumoral cells, as increased ROS levels, leading to DNA damage and topoisomerase II inhibition. Its binding interactions with topoisomerase II were investigated, showing knowledges about SAR and performing molecular modeling studies.

\subsection{PP1 and PP2}

Dysregulation of RET signaling by oncogenic mutation, gene rearrangement, overexpression or transcriptional upregulation is involved in different human cancers (thyroid, breast, lung, etc) [77-83].

Carlomagno et al. [84] found that the 4-amino-5-(4methylphenyl)-7-(t-butyl)pyrazolo[3,4-d]-pyrimidine (PP1) inhibited RET-derived oncoproteins with a half maximal inhibitor concentration of $80 \mathrm{nM}$. Moreover, RET/PTC3transformed cells lost proliferative autonomy and showed morphological reversion if treated with $5 \mu \mathrm{M}$ PP1. PP1 inhibited the growth of two human papillary TC (PTC) cell lines, carrying spontaneously RET/PTC1 rearrangements, and stopped anchorage-independent growth and tumorigenicity in NIH3T3 fibroblasts from nude mice, expressing the RET/PTC3 oncogene. The obtained results showed that a new treatment strategy for RET-associated neoplasms could be targeting RET oncogenes using PP1 or related compounds.

Even if PP1 has a powerful growth inhibitory activity against human TC cell lines with RET/PTC rearrangements, it is not selective for RET, as it is a strong inhibitor also of lck, Hck, and fynT kinases, and a good inhibitor of c-Src and platelet-derived growth factor receptor (PDGFR) [85]. For this reason, besides to the direct effect on the RET kinase in vitro, indirect effects mediated in vivo by the inhibition of other kinases (particularly of c-Src, a crucial downstream RET effector) cannot be excluded [86]. If this hypothesis is correct, a single molecule could be used for "multiple-signal transduction therapy" of RET-dependent tumor formation. Furthermore, PP1 has been suggested to be also an inhibitor of PDGFR and c-Src, to prevent restenosis and vascular remodeling [87].
Another pyrazolopyrimidine (PP2; 4-amino-5-(4-chlorophenyl)-7-(t-butyl)pyrazolo[3,4-d]pyrimidine) [88] is able to block the enzymatic activity of the isolated RET kinase and RET/PTC1 oncoprotein and the in vivo phosphorylation and signaling of the RET/PTC1 oncoprotein. PP2 inhibited the serum-independent growth of RET/PTC1-transformed NIH3T3 fibroblasts and of the two human PTC cell lines (TPC1 and FB2) harboring spontaneously RET/PTC1 rearrangements. Moreover, PP2 stopped the potential of invasion of type I collagen matrix exerted by TPC1 cells. Therefore, pyrazolopyrimidines could be a good novel therapy for the treatment of human cancers supporting oncogenic activation of RET.

\subsection{CLM3, CLM29 and CLM94}

Recently CLM3, (R)-1-phenethyl-N-(1-phenylethyl)-1Hpyrazolo[3,4-d]pyrimidin-4-amine, proposed for a multiple signal transduction inhibition (including the RET-TK, BRAF, EGFR, and with antiangiogenic activity) was disclosed. CLM3 showed an antiangiogenic effect with a less marked inhibitory activity on human TC cell lines, demonstrating time- and dose-dependent antiproliferative and proapoptotic effects on specific cell lines [89, 90].

Sartini et al. [91] evaluated new derivatives of CLM3 in order that they completely comply with pharmacophore requirements of the ATP binding sites of VEGFR2 and RET. The new molecules were tested for their inhibitory properties against the target TKs and for their antiproliferative effect against endothelial and human TC cell lines, revealing a promising antiproliferative profile on endothelial and MTC cell lines. The tested compounds were more efficient against the target TC cell line TT, expressing mutated RET, with respect to the lead CLM3.

Moreover, the antitumor and antiangiogenic activities of the new "cyclic amide" compound CLM94 [92], as well as those of CLM3 [93] and CLM29 (a pyrazolo[3,4d]pyrimidine, that inhibits RET, EGFR, VEGFR, and has an anti-angiogenic activity) [89], have been demonstrated in primary anaplastic TC cells. Antonelli et al. showed that CLM3 and CLM29 inhibited the migration of papillary dedifferentiated thyroid cancer (DePTC) cells. The inhibitory effect of CLM3 and CLM29 was independent from the presence of V600EBRAF mutation. A DePTC cell line (AL), with V600EBRAF mutation, was produced, which was able to grow in nu/nu mice when inoculated sc. CLM3 and CLM29 increased TSP-1 expression in the AL cell line. The antineoplastic activity of CLM3 and CLM29 may result from the combination of an antiproliferative effect associated with the increase of apoptosis in the tumoral cells and the inhibition of the migration and the neoplastic neovascularization. This last effect has been shown in vivo. In fact, a significant reduction of microvessels was observed in the CLM3-treated tumors. In addition, a significant decrease in the percentage of anti-VEGF antibody immunoreactivity in the tumor mass was also observed in the CLM3-treated group of animals. The mechanisms underlying the inhibition of the neoplastic neovascularization are probably related to the up-regulation of the main endogenous inhibitor of the angiogenesis, i.e. TSP-1; in fact, 
CLM3 and CLM29 increased TSP-1 expression in the AL cell line. TSP-1 has many antiangiogenic effect: 1 ) inducing apoptosis of endothelial replicating cells [94]; and 2) interacting with many extracellular proteins involved in the angiogenic process, such as VEGF $[95,96]$.

Ferrari et al. [97] reported the in vitro antineoplastic and antiangiogenic activities of CLM3 and CLM94 in primary cultures of MTC (pMTC) cells and the MTC cell line TT (harboring a RET C634W activating mutation) and MZCRC-1 (carrying the MEN2B RET M918T mutation). These compounds inhibited the proliferation of TT and pMTC cells in vitro, in part by increasing the level of apoptosis. The inhibitory effect of CLM3 and CLM94 seemed to be independent from the presence of RET mutation in pMTC. These results are in agreement with the possibility that CLM3 and CLM94 seem to be inhibitors of multiple signal transduction pathways (including the RET-TK, EGFR, VEGFR) and have an anti-angiogenic effect. A significant decrease in the gene expression of VEGF-A was also observed in TT cells after CLM3 and CLM94 treatments.

More recently, CLM29 was tested in MTC, both in pMTC cells obtained at surgery, and in TT cells with the C634W RET mutation [98]. CLM29 (10, 30, $50 \mu \mathrm{M})$ inhibited significantly $(\mathrm{P}<0.001)$ the proliferation, and increased the percentage of apoptotic pMTC, TT and human dermal microvascular endothelial cells. The inhibition of proliferation by CLM29 was similar in pMTC cells with/without RET mutation. TT cells were injected sc in CD $\mathrm{nu} / \mathrm{nu}$ mice, and tumor masses became detectable after 20-30 days from xenotransplantation; CLM29 $(50 \mathrm{mg} / \mathrm{kg} / \mathrm{die})$ reduced significantly tumor growth and weight, and microvessel density. These data showed the antineoplastic activity of CLM29 in MTC in vitro, and in vivo, opening the way to a future clinical evaluation [98].

\section{CONCLUSION (Table 1)}

TKIs are molecules that compete with ATP on TKRs, blocking TK activation and then oncogenic pathways; they have been studied, and some of them are right approved for the treatment of many types of cancer [99].

Among TKIs, one of the most explored chemical template is the pyrazolo[3,4- $d$ ]pyrimidine (PP) heterocyclic core, which proved to be a useful scaffold for the obtainment of effective compounds. Actually, derivatives belonging to this structural class show a large spectrum of activity, thus standing out as multi-target agents. Different PP compounds have been shown to act as: a) ABL inhibitors and antiproliferative agents against human leukemia cell lines; $b$ ) Src kinase inhibitors in neuroblastoma, medulloblastoma and osteosarcoma; c) Phospholipase D inhibitors in different neoplasias; d) Urokinase plasminogen activator inhibitors, in breast cancer.

In TC, PP1 and PP2 (inhibitors of RET, Hck, lck, and fynT kinases, and a good inhibitor of c-Src and PDGFR) showed antineoplastic activity in human papillary TC cell lines carrying spontaneous RET/PTC1 rearrangements. More recently, the new derivatives, CLM3 and CLM29, have been demonstrated to exert a multiple signal transduction inhibition (including the RET-TK, BRAF, EGFR, and with antiangiogenic activity), showing antineoplastic activity, in vitro and in vivo, in papillary dedifferentiated, medullary and anaplastic TC. These data have shown the antineoplastic activity of PP in different neoplasias, opening the way to a future clinical evaluation in human cancers.

\section{Table 1. Key messages.}

\begin{tabular}{|c|c|}
\hline 1. & $\begin{array}{l}\text { The important role of tyrosine kinases (TKs) and tyrosine kinase } \\
\text { receptors (TKRs) has been shown, that are capable of causing } \\
\text { cell transformations, giving mitogenic and survival signals, in } \\
\text { thyroid cancer (TC), and in other neoplasias. }\end{array}$ \\
\hline 2. & $\begin{array}{l}\text { Tyrosine kinase inhibitors (TKIs) are molecules that compete } \\
\text { with ATP on TKRs, blocking TK activation and then oncogenic } \\
\text { pathways. }\end{array}$ \\
\hline 3. & $\begin{array}{l}\text { Among TKIs, the pyrazolo[3,4-d]pyrimidine (PP) heterocyclic } \\
\text { core is a useful scaffold for the obtainment of effective } \\
\text { compounds, and derivatives belonging to this structural class } \\
\text { show a large spectrum of activity, thus standing out as multi- } \\
\text { target agents. }\end{array}$ \\
\hline 4. & $\begin{array}{l}\text { Different PP compounds have been shown to act as: a) ABL } \\
\text { inhibitors and antiproliferative agents against human leukemia } \\
\text { cell lines; b) Src kinase inhibitors in neuroblastoma, } \\
\text { medulloblastoma and osteosarcoma; c) Phospholipase D } \\
\text { inhibitors in different neoplasias; d) Urokinase plasminogen } \\
\text { activator inhibitors, in breast cancer. }\end{array}$ \\
\hline 5. & $\begin{array}{l}\text { In thyroid cancer (TC), PP1 and PP2 (inhibitors of RET, Hck, } \\
\text { lck, and fynT kinases, and a good inhibitor of c-Src and PDGFR) } \\
\text { showed antineoplastic activity in human papillary TC cell lines } \\
\text { with spontaneous RET/PTC1 rearrangements. }\end{array}$ \\
\hline 6. & $\begin{array}{l}\text { Recently, the new derivatives, CLM3 and CLM29, have been } \\
\text { demonstrated to exert a multiple signal transduction inhibition } \\
\text { (including the RET-TK, BRAF, EGFR, and with antiangiogenic } \\
\text { activity), showing antineoplastic activity, in vitro and in vivo, in } \\
\text { papillary dedifferentiated, medullary and anaplastic TC. }\end{array}$ \\
\hline
\end{tabular}

\section{LIST OF ABBREVIATIONS}

$\begin{array}{ll}\text { ADME }= & \begin{array}{l}\text { Absorption, distribution, metabolism, and } \\ \text { excretion }\end{array} \\ = & \begin{array}{l}\text { R)-1-phenethyl-N-(1-phenylethyl)-1H- } \\ \text { pyrazolo[3,4-d]pyrimidin-4-amine }\end{array} \\ \text { CLM3 } \quad= & \text { Epidermal growth factor receptor } \\ \text { EGFR } \quad= & \text { Medullary thyroid cancer } \\ \text { MTC } & =\text { Papillary dedifferentiated thyroid cancer } \\ \text { DePTC } \quad & \text { Papillary thyroid cancer } \\ \text { PTC } & =\text { Phosphatidic acid } \\ \text { PA } & =\end{array}$




\begin{tabular}{|c|c|c|}
\hline PDGFR & $=$ & Platelet-derived growth factor receptor \\
\hline pMTC & $=$ & Primary cultures of MTC \\
\hline PP & $=$ & Pyrazolo $[3,4-d]$ pyrimidine \\
\hline PP1 & $=$ & $\begin{array}{l}\text { 4-amino-5-(4-methylphenyl)-7-(t-butyl) } \\
\text { pyrazolo[3,4-d]-pyrimidine }\end{array}$ \\
\hline PP2 & $=$ & $\begin{array}{l}\text { 4-amino-5-(4-chloro-phenyl)-7-(t-butyl) } \\
\text { pyrazolo[3,4-d]pyrimidine }\end{array}$ \\
\hline ROS & $=$ & Reactive oxygen species \\
\hline SAR & $=$ & Structure activity relationship \\
\hline $\mathrm{TC}$ & $=$ & Thyroid cancer \\
\hline TKs & $=$ & Tyrosine kinases \\
\hline TKIs & $=$ & Tyrosine kinase inhibitors \\
\hline TKRs & $=$ & Tyrosine kinase receptors \\
\hline uPA & $=$ & Urokinase plasminogen activator \\
\hline uPAR & $=$ & uPA receptor \\
\hline VEGFR & $=$ & Vascular endothelial growth factor rece \\
\hline
\end{tabular}

\section{CONFLICT OF INTEREST}

The author(s) confirm that this article content has no conflict of interest.

\section{ACKNOWLEDGEMENTS}

Declared none.

\section{SUPPLEMENTARY MATERIAL}

Supplementary material is available on the publisher's web site along with the published article.

\section{REFERENCES}

[1] Knauf, J.A. Does the epidermal growth factor receptor play a role in the progression of thyroid cancer? Thyroid, 2011, 21(11), 11711174.

[2] Ferrara, N. Vascular endothelial growth factor: basic science and clinical progress. Endocr. Rev., 2004, 25(4), 581-611.

[3] de Groot, J.W.; Links, T.P.; Plukker, J.T.; Lips, C.J.; Hofstra, R.M. RET as a diagnostic and therapeutic target in sporadic and hereditary endocrine tumors. Endocr. Rev., 2006, 27(5), 535-60.

[4] Romei, C.; Elisei, R. RET/PTC translocations and clinicopathological features in human papillary thyroid carcinoma. Front. Endocrinol. (Lausanne), 2012, 3, 54.

[5] Howell, G.M.; Hodak, S.P.; Yip, L. RAS mutations in thyroid cancer. Oncologist, 2013, 18(8), 926-932.

[6] Nikiforov, Y.E.; Nikiforova, M.N. Molecular genetics and diagnosis of thyroid cancer. Nat. Rev. Endocrinol., 2011, 7(10): 569-580.

[7] De Roock, W.; De Vriendt, V.; Normanno, N.; Ciardiello, F.; Tejpar, S. KRAS, BRAF, PIK3CA, and PTEN mutations: implications for targeted therapies in metastatic colorectal cancer. Lancet Oncol., 2011, 12(6), 594-603.

[8] Ledford, H. Cancer: The Ras renaissance. Nature, 2015, 520(7547), 278-280.

[9] Rosen, L.S. VEGF-targeted therapy: therapeutic potential and recent advances. Oncologist., 2005, 10(6), 382-391.
[10] Cunha, L.L.; Marcello, M.A.; Ward, L.S. The role of the inflammatory microenvironment in thyroid carcinogenesis. Endocr. Relat. Cancer, 2014, 21(3), R85-R103.

[11] Antonelli, A.; Fallahi, P.; Ferrari, S.M.; Pupilli, C.; d'Annunzio, G.; Lorini, R.; Vanelli, M.; Ferrannini, E. Serum Th1 (CXCL10) and Th2 (CCL2) chemokine levels in children with newly diagnosed Type 1 diabetes: a longitudinal study. Diabet. Med., 2008, 25(11), 1349-1353.

[12] Antonelli, A.; Ferri, C.; Fallahi, P.; Ferrari, S.M.; Frascerra, S.; Carpi, A.; Nicolini, A.; Ferrannini, E. Alpha-chemokine CXCL10 and beta-chemokine CCL2 serum levels in patients with hepatitis $\mathrm{C}$-associated cryoglobulinemia in the presence or absence of autoimmune thyroiditis. Metabolism, 2008, 57(9), 1270-1277.

[13] Zeng, W.; Chang, H.; Ma, M.; Li, Y. CCL20/CCR6 promotes the invasion and migration of thyroid cancer cells via NF-kappa B signaling-induced MMP-3 production. Exp. Mol. Pathol., 2014, 97(1), 184-190.

[14] Melillo, R.M.; Cartellone, M.D.; Guarino, V.; De Falco, V.; Cirafici, A.M.; Salvatore, G.; Caiazzo, F.; Basolo, F.; Giannini, R.; Kruhoffer, M.; Orntoft, T.; Fusco, A.; Santoro, M. The RET/PTCRAS-BRAF linear signaling cascade mediates the motile and mitogenic phenotype of thyroid cancer cells. J. Clin. Invest., 2005, 115(4), 1068-1081

[15] Antonelli, A.; Ferrari, S.M.; Fallahi, P.; Frascerra, S.; Piaggi, S.; Gelmini, S.; Lupi, C.; Minuto, M.; Berti, P.; Benvenga, S.; Basolo, F.; Orlando, C.; Miccoli, P. Dysregulation of secretion of CXC alpha-chemokine CXCL10 in papillary thyroid cancer: modulation by peroxisome proliferator-activated receptor-gamma agonists. Endocr. Relat. Cancer, 2009, 16(4), 1299-1311.

[16] Lippitz, B.E. Cytokine patterns in patients with cancer: a systematic review. Lancet Oncol., 2013, 14(6), e218-e228.

[17] Murphy, P.M. Chemokines and the molecular basis of cancer metastasis. N. Engl. J. Med., 2001, 345(11), 833-835.

[18] Wells, S.A. Jr.; Santoro, M. Update: the status of clinical trials with kinase inhibitors in thyroid cancer. J. Clin. Endocrinol. Metab., 2014, 99(5), 1543-1555.

[19] Ye, L.; Santarpia, L.; Gagel, R.F. The evolving field of tyrosine kinase inhibitors in the treatment of endocrine tumors. Endocr. Rev., 2010, 31(4), 578-599.

[20] Elisei, R.; Cosci, B.; Romei, C.; Bottici, V.; Ronzini, G.; Molinaro, E.; Agate, L.; Vivaldi, A.; Faviana, P.; Basolo, F.; Miccoli, P.; Berti, P.; Pacini, F.; Pinchera, A. Prognostic significance of somatic RET oncogene mutations in sporadic medullary thyroid cancer: a 10-year follow-up study. J. Clin. Endocrinol. Metab., 2008, 93(3), 682-687.

[21] Lanzi, C.; Cassinelli, G.; Nicolini, V.; Zunino, F. Targeting RET for thyroid cancer therapy. Biochem. Pharmacol., 2009, 77(3), 297309.

[22] Biglietto, G.; Maglione, D.; Rambaldi, M.; Cerutti, J.; Romano, A.; Trapasso, F.; Fedele, M.; Ippolito, P.; Chiappetta, G.; Botti, G. Upregulation of vascular endothelial growth factor (VEGF) and downregulation of placenta growth factor (PIGF) associated with malignancy in human thyroid tumors and cell lines. Oncogene, 1995, 11(8), 1569-1579.

[23] Ye, L.; Santarpia, L.; Gagel, R.F. Targeted therapy for endocrine cancer: the medullary thyroid carcinoma paradigm. Endocr. Pract., 2009, 15(6), 597-604.

[24] Gild, M.L.; Bullock, M.; Robinson, B. G.; Clifton-Bligh, R. Multikinase inhibitors: a new option for the treatment of thyroid cancer. Nat. Rev. Endocrinol., 2011, 7(10), 617-624.

[25] Baccarani, M.; Castagnetti, F.; Gugliotta, G.; Rosti, G. A review of the European LeukemiaNet recommendations for the management of CML. Ann. Hematol., 2015, 94 (Suppl 2), 141-147.

[26] Nishida, T.; Doi, T.; Naito, Y. Tyrosine kinase inhibitors in the treatment of unresectable or metastatic gastrointestinal stromal tumors. Expert Opin. Pharmacother., 2014, 15(14), 1979-1989.

[27] Fishman, M.N.; Tomshine, J.; Fulp, W.J.; Foreman, P.K. A systematic review of the efficacy and safety experience reported for sorafenib in advanced renal cell carcinoma (RCC) in the postapproval setting. PLoS One, 2015, 10(4), e0120877.

[28] Tejeda-Maldonado, J.; García-Juárez, I.; Aguirre-Valadez, J.; González-Aguirre, A.; Vilatobá-Chapa, M.; Armengol-Alonso, A.; Escobar-Penagos, F.; Torre, A.; Sánchez-Ávila, J.F.; Carrillo- 
Pérez, D.L. Diagnosis and treatment of hepatocellular carcinoma: An update. World J. Hepatol., 2015, 7(3), 362-376.

[29] Fallahi, P.; Ferrari, S.M.; Santini, F.; Corrado, A.; Materazzi, G.; Ulisse, S.; Miccoli, P.; Antonelli, A. Sorafenib and thyroid cancer. BioDrugs, 2013, 27(6), 615-628.

[30] Chougnet, C.N.; Schlumberger, M.; Leboulleux, S.; Baudin, E. Vandetanib, in the management of patients with locally advanced or metastatic medullary thyroid carcinomas. Bull. Cancer, 2014, 101(9), 891-895.

[31] Durante, C.; Paciaroni, A.; Plasmati, K.; Trulli, F.; Filetti, S. Vandetanib: opening a new treatment practice in advanced medullary thyroid carcinoma. Endocrine, 2013, 44(2), 334-342.

[32] Nagilla, M.; Brown, R.L.; Cohen, E.E. Cabozantinib for the treatment of advanced medullary thyroid cancer. Adv. Ther., 2012, 29(11), 925-934.

[33] Goldenberg, M.M. Pharmaceutical approval update. P.T, 2013, 38(2), 86-95.

[34] van Leeuwen, R.W.; van Gelder, T.; Mathijssen, R.H.; Jansman, F.G. Drug-drug interactions with tyrosine-kinase inhibitors: a clinical perspective. Lancet Oncol., 2014, 15(8):e315-e326.

[35] Robins, R.K. Potential purine antagonists. I. Synthesis of some 4,6substituted pyrazolo [3,4-d]pyrimidines. J. Am. Chem. Soc., 1956, 78, 784-790.

[36] Dinakaran, V.S.; Bomma, B.; Srinivasan, K.K. Fused pyrimidines: The heterocycle of diverse biological and pharmacological significance. Der Pharma Chemica, 2012, 4(1), 255-265.

[37] Salaheldina A.M., Oliveira-Camposa A. M. F., Rodriguesa L. M. Heterocyclic synthesis with nitriles: synthesis of pyrazolopyrimidine and pyrazolopyridine derivatives. Synthetic Communications, 2009, 39, 1186-1195.

[38] Ojha, R.P.; Roychoudhury, M.; Sanyal, N.K.J. Interaction energy studies on pyrazolopyrimidine nucleoside antibiotics - A theoretical study: Oxoformycin B. J. Biosci., 1987, 12(3), 311-320.

[39] Mahajan, K.; Mahajan, N.P. ACK1 tyrosine kinase: targeted inhibition to block cancer cell proliferation. Cancer Lett., 2013, 338(2), 185-192.

[40] Chern, J.H.; Shia, K.S.; Hsu, T.A.; Tai, C.L.; Lee, C.C.; Lee, Y.C.; Chang, C.S.; Tseng, S.N.; Shih, S.R. Design, synthesis, and structure-activity relationships of pyrazolo[3,4-d]pyrimidines: a novel class of potent enterovirus inhibitors. Bioorg. Med. Chem. Lett., 2004, 14(10), 2519-2525.

[41] Rideout, J.L.; Krenitsky, T.A.; Chao, E.Y.; Elion, G.B.; Williams, R.B.; Latter, V.S. Pyrazolo[3,4-d]pyrimidine ribonucleosides as anticoccidials. 3. Synthesis and activity of some nucleosides of 4[(arylalkenyl)thio]pyrazolo[3,4-d]pyrimidines. J. Med. Chem., 1983, 26(10), 1489-1494.

[42] Bondock, S.; Rabie, R.; Etman, H. A.; Fadda, A.A. Synthesis and antimicrobial activity of some new heterocycles incorporating antipyrine moiety. Eur. J. Med. Chem., 2008, 43(10), 2122-2129.

[43] Bakavoli, M.; Bagherzadeh, G.; Vaseghifar, M.; Shiri, A.; Pordel, M.; Mashreghi, M.; Pordeli, P.; Araghi, M. Synthesis and antimicrobial activity of some new heterocycles incorporating antipyrine moiety. Eur. J. Med. Chem., 2010, 45(2), 647-650.

[44] Raffa, D.; Maggio, B.; Plescia, F.; Cascioferro, S.; Raimondi, M.V.; Plescia, S.; Cusimano, M.G. Pyrazolo[3,4-d]pyrimidine derivatives as COX-2 selective inhibitors: synthesis and molecular modelling studies. Arch. Pharm., 2009, 342(6), 321-326.

[45] Celano, M.; Schenone, S.; Cosco, D.; Navarra, M.; Puxeddu, E.; Racanicchi, L.; Brullo, C.; Varano, E.; Alcaro, S.; Ferretti, E.; Botta, G.; Filetti, S.; Fresta, M.; Botta, M.; Russo, D. Cytotoxic effects of a novel pyrazolopyrimidine derivative entrapped in liposomes in anaplastic thyroid cancer cells in vitro and in xenograft tumors in vivo. Endocr. Relat. Cancer, 2008, 15(2), 499510.

[46] Baviskar, A.T.; Banerjee, U.C.; Gupta, M.; Singh, R.; Kumar, S.; Gupta, M.K.; Kumar, S.; Raut, S.K.; Khullar, M.; Singh, S.; Kumar, R. Synthesis of imine-pyrazolopyrimidinones and their mechanistic interventions on anticancer activity. Bioorg. Med. Chem., 2013, 21 (18), 5782-5793.

[47] Anderson, J.D.; Cottam, H.B.; Larson, S.B.; Dee Nord, L.; Revankar, G.R.; Robins, R.K. Synthesis of certain pyrazolo[3,4d]pyrimidin-3-one nucleosides. J. Heterocycl. Chem., 1990, 27(2), 439-453.
[48] Trivedi, A.R.; Dholariya, B.H.; Vakhariya, C.P.; Dodiya, D.K.; Ram, H.K.; Kataria, V.B.; Siddiqui, A.B.; Shah, V.H. Synthesis and anti-tubercular evaluation of some novel pyrazolo[3,4d]pyrimidine derivatives. Med. Chem. Res., 2012, 21(8), $1887-$ 1891

[49] Ghorab, M.M.; Ragab, F.A.; Alqasoumi, S.I.; Alafeefy, A.M.; Aboulmagd, S.A. Synthesis of some new pyrazolo[3,4d]pyrimidine derivatives of expected anticancer and radioprotective activity. Eur. J. Med. Chem., 2010, 45(1), 171-178.

[50] Chauhan, M.; Kumar, R. Medicinal attributes of pyrazolo[3,4d]pyrimidines: A review. Bioorg. Med. Chem., 2013, 21(18), 56575668

[51] Manetti, F.; Brullo, C.; Magnani, M.; Mosci, F.; Chelli, B.; Crespan, E.; Schenone, S.; Naldini, A.; Bruno, O.; Trincavelli, M L.; Maga, G.; Carraro, F.; Martini, C.; Bondavalli, F.; Botta, M. structure-based optimization of pyrazolo[3,4-d]pyrimidines as $\mathrm{Abl}$ inhibitors and antiproliferative agents toward human leukemia cell lines. J. Med. Chem., 2008, 51(5), 1252-1259.

[52] Radi, M.; Dreassi, E.; Brullo, C.; Crespan, E.; Tintori, C. Bernardo, V.; Valoti, M.; Zamperini, C.; Daigl, H.; Musumeci, F. Design, synthesis, biological activity, and ADME properties of pyrazolo[3,4-d]pyrimidines active in hypoxic human leukemia cells: a lead optimization study. J. Med. Chem., 2011, 54(8), 26102626.

[53] Radi, M.; Tintori, C.; Musumeci, F.; Brullo, C.; Zamperini, C.; Drenassi, E.; Fallacara, A.; Vignaioli, G.; Crespan, E.; Zanoli, S.; Laurenzana, I.; Filippi, I.; Maga, G.; Schenone, S.; Angelucci, A.; Botta, M. Design, synthesis, and biological evaluation of pyrazolo[3,4-d]pyrimidines active in vivo on the Bcr-Abl T315I mutant. J. Med. Chem., 2013, 56(13), 5382-5394.

[54] Tintori, C.; Fallacara, A.L.; Radi, M.; Zamperini, C.; Dreassi, E.; Crespan, E.; Maga, G.; Schenone, S.; Musumeci, F.; Brullo, C.; Richters, A.; Gasparrini, F.; Angelucci, A.; Festuccia, C.; Delle Monache, S.; Rauh, D.; Botta, M. Combining X-ray crystallography and molecular modeling toward the optimization of pyrazolo[3,4-d]pyrimidines as potent c-Src inhibitors active in vivo against neuroblastoma. J. Med. Chem., 2015, 58(1), 347-361.

[55] Brunton, V.G.; Frame, M.C. Src and focal adhesion kinase as therapeutic targets in cancer. Curr. Opin. Pharmacol., 2008, 8(4), 427-432.

[56] Grant, S.; Dent, P. Kinase inhibitors and cytotoxic drug resistance. Clin. Cancer Res., 2004, 10, 2205-2207.

[57] Spreafico, A.; Schenone, S.; Serchi, T.; Orlandini, M.; Angelucci, A.; Magrini, D.; Bernardini, G.; Collodel, G.; Di Stefano, A.; Tintori, C.; Bologna, M.; Manetti, F.; Botta, M.; Santucci, A. Antiproliferative and proapoptotic activities of new pyrazolo[3,4d]pyrimidine derivative Src kinase inhibitors in human osteosarcoma cells. FASEB J., 2008, 22(5), 1560-1571.

[58] Rossi, A.; Schenone, S.; Angelucci, A.; Cozzi, M.; Caracciolo, V.; Pentimalli, F.; Puca, A.; Pucci, B.; La Montagna, R.; Bologna, M.; Botta, M.; Giordano, A. New pyrazolo-[3,4-d]-pyrimidine derivative Src kinase inhibitors lead to cell cycle arrest and tumor growth reduction of human medulloblastoma cells. FASEB J., 2010, 24(8), 2881-2892.

[59] Brazidec, L.; Pasis, A.; Tam, B.; Boykin, C.; Black, C.; Wang, D.; Claassen, G.; Chong, J.-H.; Chao, J.; Fan, J.; Nguyen, K.; Silvian, L.; Ling, L.; Zhang, L.; Choi, M.; Teng, M.; Pathan, N.; Zhao, S.; Li, T.; Taveras, A. Synthesis, SAR and biological evaluation of 1,6-disubstituted-1H-pyrazolo[3,4-d]pyrimidines as dual inhibitors of Aurora kinases and CDK1. Bioorg. Med. Chem. Lett., 2012, 22(5), 2070-2074.

[60] Brown H.A., Henage L.G., Preininger A.M., Xiang Y., Exton J.H. Biochemical analysis of phospholipase D. Methods. Enzymol., 2007, 434, 49-87.

[61] Foster D.A. Phosphatidic acid signalling to mTOR: signals for the survival of human cancer cells. Biochim. Biophys. Acta, 2009, 1791(9), 949-955.

[62] Zhao, Y.; Ehara, H.; Akao, Y.; Shamoto, M.; Nakagawa, Y.; Banno, Y.; Deguchi, T.; Ohishi, N.; Yagi, K.; Nozawa, Y. Increased activity and intranuclear expression of phospholipase D2 in human renal cancer. Biochem. Biophys. Res. Commun., 2000, $278(1), 140-143$ 
[63] Uchida, N.; Okamura, S.; Kuwano, H. Phospholipase D activity in human gastric carcinoma. Anticancer. Res., 1999, 19(1B), 671-676.

[64] Yamada, Y.; Hamajima, N.; Kato, T.; Iwata, H.; Yamamura, Y.; Shinoda, M.; Suyama, M.; Mitsudomi, T.; Tajima, K.; Kusakabe, S.; Yoshida, H.; Banno, Y.; Akao, Y.; Tanaka, M.; Nozawa, Y. Association of a polymorphism of the phospholipase $\mathrm{D}(2)$ gene with the prevalence of colorectal cancer. J. Mol. Med. (Berl.), 2003, $81(2), 126-131$.

[65] Kulkarni, A.; Quang, P.; Curry, V.; Keyes, R.; Zhou, W.; Cho, H.; Baffoe, J.; Török, B.; Stieglitz, K. 1,3-disubstituted-4aminopyrazolo [3, 4-d]pyrimidines, a new class of potent inhibitors for phospholipase D. Chem. Biol. Drug. Des., 2014, 84(3), 270281.

[66] Bishop, A.C.; Kung, C.; Shah, K.; Witucki, L.; Shokat, K.M.; Liu, Y. Generation of monospecific nanomolar tyrosine kinase inhibitors via a chemical genetic approach. J. Am. Chem. Soc., 1999, 121, 627-631.

[67] Apsel, B.; Blair, J.A.; Gonzalez, B.; Nazif, T.M.; Feldman, M.E.; Aizenstein, B.; Hoffman, R.; Williams, R.L.; Shokat, K.M.; Knight, Z.A. Targeted polypharmacology: discovery of dual inhibitors of tyrosine and phosphoinositide kinases. Nat. Chem. Biol., 2008, 4(11), 691-699.

[68] Lin, Y.; Peng, N.; Li, J.; Zhuang, H.; Hua, Z.C. Herbal compound triptolide synergistically enhanced antitumor activity of aminoterminal fragment of urokinase. Mol. Cancer, 2013, 12, 54.

[69] Tamura, T.; Morita, E.; Kawai, S.; Okada, R.; Naito, M.; Wakai, K.; Hori, Y.; Kondo, T.; Hamajima, N. Significant association of urokinase plasminogen activator Pro141Leu with serum lipid profiles in a Japanese population. Gene, 2013, 524(2), 363-367.

[70] Blasi, F.; Carmeliet, P. uPAR: a versatile signalling orchestrator. Nat. Rev. Mol. Cell Biol., 2002, 3(12), 932-943.

[71] Andreasen, P.A.; Kjøller, L.; Christensen, L.; Duffy, M. J. The urokinase-type plasminogen activator system in cancer metastasis: a review. Int. J. Cancer, 1997, 72(1), 1-22.

[72] Meyer, T.; Hart, I.R. Mechanisms of tumour metastasis. Eur. J. Cancer, 1998, 34(2), 214-221.

[73] Skehan, P.; Storeng, R.; Scudiero, D.; Monks, A.; McMahon, J.; Vistica, D.; Warren, J.T.; Bokesch, H.; Kenney, S.; Boyd, M.R. New colorimetric cytotoxicity assay for anticancer-drug screening. J. Natl. Cancer Inst., 1990, 82(13), 1107-1112.

[74] Shamroukh, A.H.; Rashad, A.E.; Abdel-Megeid, R.E.; Ali, H.S.; Ali, M.M. Some pyrazole and pyrazolo[3,4-d]pyrimidine derivatives: synthesis and anticancer evaluation. Arch. Pharm. (Weinheim), 2014, 347(8), 559-565.

[75] Rashad, A.E.; Mahmoud, A.E.; Ali, M.M. Synthesis and anticancer effects of some novel pyrazolo[3,4-d]pyrimidine derivatives by generating reactive oxygen species in human breast adenocarcinoma cells. Eur. J. Med. Chem., 2011, 46(4), 10191026.

[76] Hassan, G.S.; Kadry, H.H.; Abou-Seri, S.M.; Ali, M.M.; Mahmoud, A.E. Synthesis and in vitro cytotoxic activity of novel pyrazolo[3,4-d]pyrimidines and related pyrazole hydrazones toward breast adenocarcinoma MCF-7 cell line. Bioorg. Med. Chem., 2011, 19(22), 6808-6817.

[77] Plaza-Menacho, I.; Mologni, L.; McDonald, N.Q. Mechanisms of RET signaling in cancer: current and future implications for targeted therapy. Cell. Signal., 2014, 26(8), 1743-1752.

[78] Krampitz, G.W.; Norton, J.A. RET gene mutations (genotype and phenotype) of multiple endocrine neoplasia type 2 and familial medullary thyroid carcinoma. Cancer, 2014, 120(13), 1920-1931.

[79] Antonelli, A.; Ferri, C.; Fallahi, P.; Cazzato, M.; Ferrari, S.M.; Sebastiani, M.; Ferrannini, E. Clinical and subclinical autoimmune thyroid disorders in systemic sclerosis. Eur. J. Endocrinol., 2007, 156(4), 431-437.

[80] Antonelli, A.; Fallahi, P.; Ferrari, S.M.; Mancusi, C.; Colaci, M.; Santarpia, L.; Ferri, C. RET TKI: Potential role in thyroid cancers. Curr. Oncol. Rep., 2012, 14(2), 97-104.

[81] Reungwetwattana, T.; Dy, G.K. Targeted therapies in development for non-small cell lung cancer. J. Carcinog., 2013, 12, 22.

[82] Mulligan, L.M. RET revisited: expanding the oncogenic portfolio. Nat. Rev. Cancer, 2014, 14(3), 173-186.
[83] Morandi, A.; Plaza-Menacho, I.; Isacke, C.M. RET in breast cancer: functional and therapeutic implications. Trends Mol. Med., 2011, 17(3), 149-157.

[84] Carlomagno, F.; Vitagliano, D.; Guida, T.; Napolitano, M.; Vecchio, G.; Fusco, A.; Gazit, A.; Levitzki, A.; Santoro, M. The kinase inhibitor PP1 blocks tumorigenesis induced by RET oncogenes. Cancer Res., 2002, 62(4), 1077-1082.

[85] Hanke, J.H.; Gardner, J.P.; Dow, R.L.; Changelian, P.S.; Brissette, W.H.; Weringer, E.J.; Pollok, B.A.; Connelly, P.A. Discovery of a novel, potent, and Src family-selective tyrosine kinase inhibitor. Study of Lck- and FynT-dependent T cell activation. J. Biol. Chem., 1996, 271(2), 695-701.

[86] Melillo, R.M.; Barone, M.V.; Lupoli, G.; Cirafici, A.M.; Carlomagno, F.; Visconti, R.; Matoskova, B.; Di Fiore, P.P.; Vecchio, G.; Fusco, A.; Santoro, M. Ret-mediated mitogenesis requires Src kinase activity. Cancer Res., 1999, 59(5), 1120-1126.

[87] Waltenberger, J.; Uecker, A.; Kroll, J.; Frank, H.; Mayr, U.; Bjorge, J.D.; Fujita, D.; Gazit, A.; Hombach, V.; Levitzki, A.; Böhmer, F.D. A dual inhibitor of platelet-derived growth factor $\beta$ receptor and Src kinase activity potently interferes with motogenic and mitogenic responses to PDGF in vascular smooth muscle cells. A novel candidate for prevention of vascular remodeling. Circ. Res., 1999, 85(1), 12-22.

[88] Carlomagno, F.; Vitagliano, D.; Guida, T.; Basolo, F.; Castellone, M.D.; Melillo, R.M.; Fusco, A.; Santoro, M. Efficient inhibition of RET/papillary thyroid carcinoma oncogenic kinases by 4-amino-5(4-chloro-phenyl)-7-(t-butyl)pyrazolo[3,4-d]pyrimidine (PP2). J. Clin. Endocrinol. Metab., 2003, 88(4), 1897-1902.

[89] Antonelli, A.; Bocci, G.; La Motta, C.; Ferrari, S. M.; Fallahi, P.; Fioravanti, A.; Sartini, S.; Minuto, M.; Piaggi, S.; Corti, A.; Alì, G.; Berti, P.; Fontanini, G.; Danesi, R.; Da Settimo, F.; Miccoli, P. Novel pyrazolopyrimidine derivatives as tyrosine kinase inhibitors with antitumoral activity in vitro and in vivo in papillary dedifferentiated thyroid cancer. J. Clin. Endocrinol. Metab., 2011, 96(2), E288-E296.

[90] Bocci, G.; Fioravanti, A.; La Motta, C.; Orlandi, P.; Canu, B.; Di Desidero, T.; Mugnaini, L.; Sartini, S.; Cosconati, S.; Frati, R.; Antonelli, A.; Berti, P.; Miccoli, P.; Da Settimo, F.; Danesi, R. Antiproliferative and proapoptotic activity of CLM3, a novel multiple tyrosine kinase inhibitor, alone and in combination with SN-38 on endothelial and cancer cells. Biochem. Pharmacol., 2011, 81(11), 1309-1316.

[91] Sartini, S.; Coviello, V.; Bruno, A.; La Pietra, V.; Marinelli, L.; Simorini, F.; Taliani, S.; Salerno, S.; Marini, A.M.; Fioravanti, A.; Orlandi, P.; Antonelli, A.; Da Settimo, F.; Novellino, E.; Bocci, G.; La Motta, C. structure-based optimization of tyrosine kinase inhibitor CLM3. Design, synthesis, functional evaluation, and molecular modeling studies. J. Med. Chem., 2014, 57(54), 12251235.

[92] Antonelli, A.; Bocci, G.; La Motta, C.; Ferrari, S.M.; Fallahi, P.; Ruffilli, I.; Di Domenicantonio, A.; Fioravanti, A.; Sartini, S.; Minuto, M.; Piaggi, S.; Corti, A.; Alì, G.; Di Desidero, T.; Berti, P.; Fontanini, G.; Danesi, R.; Da Settimo, F.; Miccoli, P. CLM94, a novel cyclic amide with anti-VEGFR-2 and antiangiogenic properties, is active against primary anaplastic thyroid cancer in vitro and in vivo. J. Clin. Endocrinol. Metab., 2012, 97(4), E528E536.

[93] Antonelli, A.; Bocci, G.; Fallahi, P.; La Motta, C.; Ferrari, S.M.; Mancusi, C.; Fioravanti, A.; Di Desidero, T.; Sartini, S.; Corti, A.; Piaggi, S.; Materazzi, G.; Spinelli, C.; Fontanini, G.; Danesi, R.; Da Settimo, F.; Miccoli, P. CLM3, a multitarget tyrosine kinase inhibitor with antiangiogenic properties, is active against primary anaplastic thyroid cancer in vitro and in vivo. J. Clin. Endocrinol. Metab., 2014, 99(4), E572-E581.

[94] Mirochnik, Y.; Kwiatek, A.; Volpert, O.V. Thrombospondin and apoptosis: molecular mechanisms and use for design of complementation treatments. Curr. Drug Targets, 2008, 9(10), 851-862.

[95] Tan, K.; Lawler, J. The interaction of Thrombospondins with extracellular matrix proteins. J. Cell. Commun. Signal., 2009, 3(34), 177-187.

[96] Zhang, X.; Kazerounian, S.; Duquette, M.; Perruzzi, C.; Nagy, J.A.; Dvorak, H.F.; Parangi, S.; Lawler, J. Thrombospondin-1 modulates 
vascular endothelial growth factor activity at the receptor level. FASEB J., 2009, 23(10), 3368-3376.

[97] Ferrari, S.M.; Fallahi, P.; La Motta, C.; Bocci, G.; Corrado, A.; Materazzi, G.; Galleri, D.; Piaggi, S.; Danesi, R.; Da Settimo, F.; Miccoli, P.; Antonelli, A. Antineoplastic activity of the multitarget tyrosine kinase inhibitors CLM3 and CLM94 in medullary thyroid cancer in vitro. Surgery, 2014, 156(5), 1167-1176.

[98] Antonelli, A.; Bocci, G.; La Motta, C.; Ferrari, S.M.; Fallahi, P.; Corrado, A.; Fioravanti, A.; Sartini, S.; Orlandi, P.; Piaggi, S.;
Corti, A.; Materazzi, G.; Galleri, D.; Ulisse, S.; Fontanini, G.; Danesi, R.; Da Settimo, F.; Miccoli, P. CLM29, a multi-target pyrazolopyrimidine derivative, has anti-neoplastic activity in medullary thyroid cancer in vitro and in vivo. Mol. Cell. Endocrinol., 2014, 393(1-2), 56-64.

[99] Krause, D.S.; Van Etten, R.A. Tyrosine kinases as targets for cancer therapy. N. Engl. J. Med., 2005, 353(2), 172-187. 